\title{
STUDI ANALSIS KEBUTUHAN LIFT THE FLAP BOOK SEBAGAI MEDIA PEMBELAJARAN UNTUK MENGURANGI PERILAKU GADGET ADDICTION PADA SISWA TINGKAT DASAR
}

\author{
Dewi Endah Puspitasari', Dewi Septiyaningsih², Widya Loka Lulu Kusuma \\ Wardani ${ }^{3}$ \\ 1,2Bimbingan dan Konseling, FIP, Universitas Negeri Yogyakarta \\ ${ }^{3}$ Teknologi Pendidikan, FIP, Universitas Negeri Yogyakarta \\ 1'dewiendahpuspitasari@gmail.com; 'dewiseptiyaningsih1@gmail.com, \\ 3widyaloka10@gmail.com
}

\begin{abstract}
Gadgets have now become the daily necessities of modern society, ranging from laptops, tablets to smartphones. The survey (theAsian Parent Insight with Samsung Kidstime: 2014) states that 98\% of children in Southeast Asia have used a smartphone / tablet. The high intensity of the use of gadgets by children to play games and access video content is certainly a problem in itself. If in the past children often spend their free time playing with friends, studying and reading books, now children prefer to spend their time playing gadgets. Though the end of childhood (elementary school children) is an important time to interact with friends. Activities to interact with friends include playing in groups. Play is important for the physical, psychological, and social development of children. By playing in groups, children interact with friends so they can provide valuable lessons for children to tolerate with fellow friends. (Rita Eka Izzaty, et al., 2008: 112). This research is to find out: 1) the length of time using a gadget by elementary school students, 2) the content that is accessed when using a gadget. This research uses qualitative research. The conclusion is that the flap book lift can be used as a learning medium to reduce the behavior of gadget addiction in elementary level students.
\end{abstract}

Keywords: Gadgets, Lift The Flap Book, Learning Media.

\begin{abstract}
ABSTRAK
Gadget kini sudah menjadi kebutuhan sehari-hari masyarakat modern, mulai dari laptop, tablet hingga smartphone. Survei (the Asian Parent Insight bersama Samsung Kidstime: 2014) menyatakan bahwa 98\% anak di Asia Tenggara telah menggunakan smartphone/tablet. Tingginya intensitas penggunaan gadget oleh anak-anak untuk bermain game dan mengakses konten video tentunya menjadi masalah tersendiri. Jika dulu anak-anak sering mengisi waktu luang dengan bermain dengan teman-teman, belajar dan membaca buku, kini anak-anak lebih suka menghabiskan waktunya untuk bermain gadget. Padahal masa kanak-kanak akhir (anak-anak Sekolah Dasar) merupakan masa yang penting untuk berinteraksi dengan teman. Kegiatan berinteraksi dengan teman meliputi bermain secara berkelompok. Bermain penting bagi perkembangan fisik, psikis, dan sosial anak. Dengan bermain secara berkelompok, anak berinteraksi dengan temannya sehingga dapat memberikan pelajaran berharga pada anak untuk bertenggang rasa
\end{abstract}


dengan sesama teman. (Rita Eka Izzaty, dkk., 2008: 112). Penelitian ini untuk mengetahui: 1) lamanya menggunakan gadget oleh siswa SD, 2) konten yang diakses saat menggunakan gadget. Penelitian ini menggunakan jenis penelitian kualitatif. Kesimpulanya adalah lift the flap book dapat digunakan sebagai media pembelajaran untuk mengurangi perilaku gadget addiction pada siswa tingkat dasar.

Kata Kunci : Gadget, Lift The Flap Book, Media Pembelajaran.

\section{A. Pendahuluan}

Pada zaman sekarang ini perkembagan teknologi telah berkembang sangat cepat, baik di negara maju maupun di negara berkembang. Banyak teknologi yang telah diciptakan salah satunya adalah gadget. Gadget kini sudah menjadi kebutuhan sehari-hari masyarakat modern, mulai dari laptop, tablet hingga smartphone. Pengguna gadget sendiri tidak hanya dari kalangan pekerja, akan tetapi sekarang ini hampir semua kalangan termasuk anak-anak menggunakan gadget terutama smartphone dalam kegiatan yang mereka lakukan setiap harinya.

Anak-anak sekarang ini sudah diperbolehkan bahkan difasilitasi smartphone oleh orang tuanya. Bahkan anak-anak Sekolah Dasar membawa smartphone ke sekolah menjadi hal yang biasa seolah anakanak tidak bisa lepas dari smartphone. Survei (the Asian Parent Insight bersama Samsung Kidstime: 2014) menyatakan bahwa 98\% anak di Asia
Tenggara telah menggunakan smartphone/ tablet. Tidak heran bila kita melihat anak balita sudah mahir menggunakan tablet atau smartphone untuk menonton kartun ataupun mendengarkan lagu kesayangannya. Sedangkan anak yang lebih besar, sudah lebih canggih lagi memanfaatkan gadget tersebut untuk bermain game. Selain itu faktanya anak-anak biasanya menggunakan gadget selama lebih dari 1 jam pada setiap kali penggunaan. Meskipun sebenarnya alasan orang tua memperbolehkan anaknya menggunakan smartphone /tablet adalah untuk keperluan edukasi. Selain itu, alasan lainnya adalah untuk hiburan, pengenalan teknologi sejak dini, serta untuk membuat mereka tenang atau sibuk.

Harapan orang tua memberikan smartphone pada anak untuk keperluan edukasi tidak sesuai dengan kenyataan yang ada. Anakanak yang menggunakan smartphone lebih sering untuk hal-hal hiburan 
semata. Survei (theAsianParent Insight bersama Samsung Kidstime: 2014) menyatakan bahwa $70 \%$ anak menggunakan smartphone untuk bermain game dan $60 \%$ untuk mengakses konten video barulah 57\% digunakan untuk mengakses aplikasi pendidikan dan $14 \%$ untuk mengakses aplikasi buku.

Tingginya intensitas penggunaan gadget oleh anak-anak untuk bermain game dan mengakses konten video tentunya menjadi masalah tersendiri. Jika dulu anak-anak sering mengisi waktu luang dengan bermain dengan teman-teman, belajar dan membaca buku, kini anak-anak lebih suka menghabiskan waktunya untuk bermain gadget. Padahal masa kanak-kanak akhir (anak-anak Sekolah Dasar) merupakan masa yang penting untuk berinteraksi dengan teman. Kegiatan berinteraksi dengan teman meliputi bermain secara berkelompok. Bermain penting bagi perkembangan fisik, psikis, dan sosial anak. Dengan bermain secara berkelompok, anak berinteraksi dengan temannya sehingga dapat memberikan pelajaran berharga pada anak untuk bertenggang rasa dengan sesama teman. (Rita Eka Izzaty, dkk., 2008: 112).
Peserta didik yang lebih sering mengisi waktu luangnya untuk bermain gadget dibandingkan dengan bermain dengan teman-temannya, tentu saja menjadi tantangan tersendiri bagi pendidik dalam mengatasi permasalahan tersebut. Oleh karena itu diperlukan gagasan baru dalam media pembelajaran yang kreatif dan inovatif untuk dapat mengurangi intensitas peserta didik dalam penggunaan gadget. Penulis menawarkan solusi kontributif berupa lift the flap book sebagai media pembelajaran untuk mengurangi perilaku gadget addiction pada siswa tingkat dasar. Buku berjendela atau buku lift the flap memiliki bentuk khusus, yaitu berjendela dan menggunakan design warna yang menarik. Buku berjendela terdapat gambar didalamnya, dimana gambar dilengkapi dengan jendela yang dapat dibuka baik keatas, kebawah, kekanan maupun kekiri serta memiliki keterangan dibaliknya. (Elvas Sugianto Efendhi, 2014: Volume 2 no 2) Dengan adanya media pembelajaran lift the flap book, siswa tingkat dasar diharapkan dapat mengurangi perilaku gadget addiction. 


\section{B. Metode Penelitian}

Jenis penelitian ini termasuk penelitian kualitatif. Penelitian kualitatif menurut Sugiyono (2010:13) merupakan metode penelitian yang digunakan untuk meneliti pada kondisi obyek yang alamiah, (sebagai lawannya adalah eksperimen) dimana peneliti adalah sebagai instrumen kunci, teknik pengumpulan data dilakukan secara triangulasi (gabungan), analisis data bersifat induktif, dan hasil penelitian kualitatif lebih menekankan makna daripada generalisasi.

Subjek penelitian dalam penelitian ini adalah siswa kelas 3 SD. Pemilihan subjek dilakukan secara acak bertujuan untuk memperoleh persebaran data serta tidak terfokus pada karakteristik tertentu pada siswa.

Pengumpulan data dalam penelitian ini dilakukan dengan beberapa metode diantaranya:

\section{Observasi}

Observasi dilakukan dengan mengamati perilaku anak dalam menggunkan gadget dan perilaku orang tua dalam memberikan gadget pada anak. Penggunaan gadget meliputi seberapa lama anak dalam menggunakan gadget serta jarak pandang anak dalam menggunkan gadget.

\section{Wawancara}

Wawancara dilakukan secara tidak terstruktur sehingga data yang diperoleh cukup dalam. Wawancara dilakukan kepada anak kelas 3 SD. Adapun fokus pertanyaan dalam wawancara yang dilakukan terkait dengan penggunaan gadget anak dan konten yang sering dibuka saat menggunkan gadget.

\section{Studi Literatur}

Studi literatur dilakukan dengan mencari referensi untuk mendukung data yang diperoleh sehingga data yang diperoleh lebih mendalam. Adapun fokus dalam studi literatur yang dilakukan terkait dampak negatif menggunakan gadget dan aktivitas lain yang dapat dilakukan selain bermain gadget.

Guna menyajikan data dan penarikan kesimpulan data dilakukan analisis data dengan menggunakan model analysis interacive model dari Miles dan Huberman (dalam Sugiyono, 2015: 338). Analisis data ini terdiri dari tiga tahapan diantaranya tahap reduksi, penyajian data, dan penarikan kesimpulan. Reduksi data merupakan kegiatan merangkum, memilih hal-hal pokok, 
memfokuskan pada hal-hal yang penting, dicari tema dan polanya dan membuang yang tidak perlu. Penyajian data dapat dilakukan dalam bentuk uraian singkat, bagan, hubungan antar kategori, flowchart dan sejenisnya. Sedangkan penarikan kesimpulan adalah penarikan kesimpulan akhir mengingat Kesimpulan awal masih bersifat sementara, dan akan berubah bila tidak ditemukan buktibukti yang kuat yang mendukung pada tahap pengumpulan data berikutnya.

\section{Hasil dan Pembahasan}

\section{Deskripsi Data}

\section{a. Observasi}

Berdasarkan obervasi yang dilakukan, ketika berada di luar lingkungan sekolah anak atau siswa tidak dapat lepas dari bermain gadget. Kondisi ini terjadi ketika anak sedang tidak bermain bersama dengan teman-temannya dan ketika orang tua memberikan gadget pada anak selagi mereka melakukan kegiatan lain dengan maksud agar anak diam dan tidak menganggu pekerjaan orang tuanya. Satu contoh adalah ketika seorang ibu akan menyuapi anak balitanya kemudian ia memberikan smartphone pada anak sulungnya agar tidak mengganggu sang adik ketika sedang disuapi. Selain itu, berdasarkan hasil observasi 3 dari 5 anak menggunakan gadget dengan jarak pandang yang terlalu dekat.

\section{b. Wawancara}

Pengambilan data berupa wawancara guna memperdalam data sebelumnya. Dari hasil analisis wawancara didapatkan bahwa setiap individu memiliki minat dan ketertarikan yang berbeda akan penggunaan gadget. Namun, berdasarkan hasil diatas kebanyakan faktor gadget addicted disebabkan oleh penggunaan aplikasi Youtube ataupun game baik menggunakan $\mathrm{hp}$ ataupun komputer.

Beberapa anak menyampaikan bahwa gadget yang sering digunakan adalah handphone dan gadget merupakan barang yang penting. Dalam sekali memamkai gadget, beberapa anak menyampaikan sekali duduk menggunakan gadget bisa 3 jam.

\section{c. Studi Literatur}

Studi literatur kami artikel jurnal menurut Febrino (2017: 7-14) kami menemukan beberapa dampak negatif yaitu yang pertama jarak pandang gadget dengan mata yang 
tidak diperhatikan dapat merusak mata sehingga membuat mata anak menjadi minus dan harus menggunakan kacamata. Anak yang terlalu asyik bermain gadget bahkan mengurangi jam tidurnya sehingga membuat anak menjadi mengantuk di kelas dan sulit berkonsentrasi saat di kelas. Pekerjaan Rumah menumpuk karena waktu belajarnya digunakan untuk bermain gadget. Tugas-tugas yang tidak kunjung diselesaikan menyebabkan prestasi belajar anak menurun.

Diperolehnya data mengenai dampak negatif terkait penggunaan gadget berlebihan maka dibutuhkan aktivitas lain sebagai pengganti bermain gadget. Menurut Lakupon (2017), karena dengan berenang selain bisa bermain di air sekaligus menikmati manfaatnya dikemudian hari. Aulia (2013), bermain musik dapat meningkatkan kemampuan otak, daya ingat, dan kreativitas.

Selain itu aktivitas lain yang menyenangkan daripada bermain gadget menurut Tarigan, H. G. (1984), membaca dapat memudahkan dalam berkomunikasi, menambah pengetahuan serta informasi baru. Manfaat menggambar menurut Sekarsari. B (2017), dapat melatih kreativitas anak untuk menciptkan suatu karya dan dapat menjadi media untuk mengekspresikan diri. Utami, Desni (2017), berkreasi dengan barang bekas dapat mengasah kreativitas anak, dan memberikan pelajaran pada anak bahwa barang bekas masih ada menfaatnya dan menjadikan anak peduli terhadap lingkungannya.

\section{Pembahasan}

a. Analisis kebutuhan lift the flap book

Buku berjendela atau buku lift the flap memiliki bentuk khusus, yaitu berjendela dan menggunakan design warna yang menarik. Buku berjendela terdapat gambar didalamnya, dimana gambar dilengkapi dengan jendela yang dapat dibuka baik keatas, kebawah, kekanan maupun kekiri serta memiliki keterangan dibaliknya. (Elvas Sugianto Efendhi, 2014: Volume 2 No. 2)

Lift the flap dikemas dengan menyusun atau menumpuk beberapa kertas, lalu mengunci salah satu sisi susunan kertas dan menyisakan sebagian besar bagian kertas agar dapat dibuka dan ditutup kembali. Lift the flap dikenal dengan mekanis kertas yang menyerupai teknis 
membuka dan menutup jendela. Selain itu, secara tidak langsung kegiatan melihat, membuka dan menutup lipatan gambar dapat melatih perkembangan motorik anak. (Dewantari, 2014).

Analisis diperlukannya lift the flap book diasarkan pada beberapa faktor meliputi:

\section{a. Tingginya angka penggunaan gadget pada anak}

Berdasarkan

survei

(theAsianParent

Insight bersama Samsung Kidstime: 2014) menyatakan bahwa $98 \%$ anak di Asia Tenggara telah menggunakan smartphone/tablet.

Anak-anak biasanya menggunakan gadget selama lebih dari 1 jam pada setiap kali penggunaan. Selain itu, berdasarkan wawancara yang telah dilakukan anak-anak bisa menggunkan gadget rata-rata 3 jam pada setiap kali penggunaan.

\section{b. Rendahnya pemanfaatan gadget} untuk kegiatan belajar

Berdasarkan

survei

(theAsianParent

Insight bersama Samsung Kidstime: 2014) menyatakan bahwa $70 \%$ anak menggunakan smartphone untuk bermain game dan $60 \%$ untuk mengakses konten video barulah $57 \%$ digunakan untuk mengakses aplikasi pendidikan dan $14 \%$ untuk mengakses aplikasi buku. Selain itu, berdasarkan wawancara yang telah dilakukan anak-anak lebih sering menggunakan gadget untuk mengakses konten video di youtube dan bermain game.

\section{c. Peluang pemanfaatan lift the}

\section{flap book}

Karena anak-anak yang lebih sering mengisi waktu luangnya untuk bermain gadget dibandingkan dengan bermain dengan teman-temannya, maka perlunya media pembelajaran yang menarik bagi anak sehingga intensitas penggunaan gadget dapat berkurang.Llift the flap book sebagai media pembelajaran untuk mengurangi perilaku gadget addiction pada siswa tingkat dasar. Buku berjendela atau buku lift the flap memiliki bentuk khusus, yaitu berjendela dan menggunakan design warna yang menarik. Buku berjendela terdapat gambar didalamnya, dimana gambar dilengkapi dengan jendela yang dapat dibuka baik keatas, kebawah, kekanan maupun kekiri serta memiliki keterangan dibaliknya. (Elvas Sugianto Efendhi, 2014: Volume 2 no 2).

Berdasarkan paparan di atas 
dapat disimpulkan bahwa lift the flap book sebagai media pembelajaran untuk menggurangi perilaku gadget addiction dibutuhkan dan diperlukan. Tingginya angka penggunaan gadget pada anak yang memungkinkan munculnya dampak negatif perlu ditindaklanjuti.

\section{Kesimpulan}

Kesimpulan yang dapat diperoleh dari karya tulis ini adalah:

1. Tingginya angka penggunaan gadget pada anak.

2 Anak sering menggunkan gadget untuk bermain game dan mengakses konten video di Youtube.

3. Lamanya intensitas anak dalam menggunakan gadget dalam sekali penggunaan.

4. Lift the flap book dapat digunakan sebagai media pembelajaran untuk mengurangi perilaku gadget addiction pada siswa tingkat dasar.

5. Diperlukan media pembelajaran lift the flap book untuk megurangi perilaku gadget addiction pada siswa tingkat dasar.

\section{DAFTAR PUSTAKA}

Aulia. 2013. Manfaat Bermain Alat Musik.

Diakses dari https://www.motherandbaby.co.i d/article/2013/12/11/1326/Manfa at-Bermain-Alat-Musik pada tanggal 15 April 2018 pukul 15.30 WIB

Efendhi, E.S. dan J. Susilowibowo. 2014. Pengembangan Bahan Ajar Buku Berjendela sebagai Pendukung Implementasi Pembelajaran Berbasis Scientific Approach pada Materi Jurnal Khusus. Jurnal Pendidikan Akuntansi. 2(2):1-6

Febrino. 2017. Tindakan Preventif Pengaruh Negatif Gadget Terhadap Anak. Noura. 1(1): 714

Izzaty, R.E. 2008. Perkembangan Peserta Didik. Yogyakarta: UNY Press

Lakupon. 2017. 11 Manfaat Luar Biasa Berenang untuk Tubuh Sehat dan Bugar. Diakses dari https://m.liputan6.com/lifestyle/r ead/3050672/11-manfaat-luarbiasa-berenang-untuk-tubuhsehat-dan-bugar

Maya, A. 2014. Survey tentang Smartphone \& Tablet - Hasilnya Mengejutkan diakses dari https://id.theasianparent.com/ha sil-survey-smartphone-yangmengejutkan/ pada tanggal 9 November 2017 Pukul 22.00 WIB

Sekarsari, Bebby. 2017. 6 Manfaat Menggambar Bagi Anak. Diakses dari http://www.1health.id/id/article/c ategory/ibu-dan-anak/6manfaat-menggambar-bagianak.html 
Tarigan, H. G. 1984. Membaca Sebagai Suatu Keterampilan Berbahasa. Bandung: Angkasa

Unantenne, Nalika. 2014. Mobile Device Usage Among Young Kids A Southeast Asia Study. Singapore: theAsianparent Insights

Sugiyono. 2010. Memahami Penelitian Kualitatif. Bandung: Alfabeta

Sugiyono. 2015. Metode Penelitian Pendidikan: Pendekatan Kuantitatif, Kualitatif, dan R\&D. Bandung: Alfabeta. 